\title{
Class Conservation Morfologi Karang berdasarkan Kedalaman pada Struktur Terumbu Karang di Pulau Kemujan dan Pulau Sintok, Karimunjawa, Jawa Tengah
}

\section{Coral Morphology Class Conservation Based on Depth of Coral Reef Structure in Kemujan and Sintok Islands, Karimunjawa, Central Java}

\author{
Renanda Nur Erviana, Pujiono Wahyu Purnomo, Supriharyono
}

\author{
Program Studi Manajemen Sumberdaya Perairan, Departemen Sumberdaya \\ Akuatik, Fakultas Perikanan Dan Ilmu Kelautan, Universitas Diponegoro \\ Jl. Prof. Soedarto, SH, Tembalang, Jawa Tengah - 50275, Telp/Fax. +6224 \\ 7474698 Email: renandanurerviana@ students.undip.ac.id
}

\begin{abstract}
ABSTRAK
Kemujan dan Sintok merupakan pulau yang termasuk ke dalam zona pemanfaatan sebagai wisata bahari dan memiliki keanekaragaman bentuk pertumbuhan karang yang tinggi. Bentuk pertumbuhan karang dibedakan menjadi karang acropora dan non-acopora dengan perbedaan morfologi seperti tipe branching, massive, encruisting, foliose, dan digitae. Analisis morfologi karang sebagai pendukung status penutupan karang dapat mengetahui kondisi terumbu karang sesuai class conservation. Tujuan penelitian ini mengetahui kualitas perairan, struktur terumbu karang, morfologi karang berdasarkan class conservation dan pengaruh kedalaman terhadap struktur serta morfologi karang di Pulau Kemujan dan Sintok. Pengambilan data dilaksanakan pada bulan November 2019. Metode penelitian yang digunakan adalah metode Underwater Photo Transect (UPT) dengan menggunakan transek sepanjang 30 meter. Data yang diambil adalah parameter kualitas perairan dan foto underwater karang. Data hasil penelitian diolah menggunakan aplikasi CPCe (Coral Point Count with Excel extensions) dan uji non parametrik dengan SPSS serta dianalisis menggunakan diagram r-K-S. Hasil penelitian menunjukkan bahwa kualitas perairan pada lokasi penelitian masih dalam keadaan normal. Persentase kelimpahan karang hidup termasuk dalam kategori sedang sampai dengan sangat baik yaitu berkisar 25,56 -76,22\%. Persentase morfologi karang berdasarkan Class conservation secara umum memiliki dominasi kelompok kompetitors $(\mathrm{K})$ atau $\mathrm{CC}=2$ yang berkisar $48,72-76,5 \%$, hal ini menunjukkan bahwa pada lokasi penelitian didominasi karang bentuk branching maupun foliose serta tidak ada pengaruh signifikan kedalaman air terhadap morfologi karang.
\end{abstract}

Kata kunci : Class Conservation, CPCe, Kedalaman, Kemujan, Morfologi Karang, Sintok

\begin{abstract}
Kemujan and Sintok are islands in the utilization zone as marine tourism and have high diversity of coral growth forms. The coral's life form can be grouped into acropora and non-acopora corals with morphological differences such as branching, massive, encruisting, foliose, and digitae types. Morphological analysis of corals as supporting the status of coral cover can determine the condition of coral reefs according to class conservation. The purpose of this study are to determine the quality of the waters, the structure of coral reefs, coral morphology based on class conservation and the influence of depth on the structure and morphology of corals in Kemujan and Sintok Islands. Data collection was carried out in November 2019. The research method used was the Underwater Photo Transect (UPT) method using a 30 meter transect. The data collected the parameters of water quality and underwater coral photos. The research data were processed using the CPCe (Coral Point Count with Excel extensions) application and non-parametric tests with SPSS and analyzed using the $r-K-S$ diagram. The results showed that the water quality at the study area was still in a normal condition. However, there was no significant effect of water depth on coral morphology. The percentage of live coral abundance was included in the moderate to very good category, ranging from 25.56 to $76.22 \%$. Percentage of coral morphology based on Class conservation generally has a predominance of competitor groups $(K)$ or CC $=2$ ranging from $48.72-76.5 \%$. Moreover, the results show that based on the coral growth forms at the study sites were dominated by branching and foliose corals and there was no significant effect of water depth on coral morphology.
\end{abstract}

Keywords: Class conservation, CPCe, Depth, Kemujan, Coral morphology, Sintok

\section{A. PENDAHULUAN}

Terumbu karang merupakan salah satu ekosistem tropis penyumbang biodiversitas penting di lautan. Faktorfaktor alami dan atau aktivitas manusia diketahui telah mempengaruhi struktur terumbu karang. Naiknya tingkat kemunculan dan kerusakan karang akibat pemutihan karang (Coral Bleaching) yaitu suatu fenomena sehubungan adanya berbagai tekanan, khususnya kenaikan suhu air laut dan pencahayaan yang tinggi (Westmacott et al, 2000). Terumbu karang merupakan salah satu ekosistem laut yang paling terancam sebagai akibat dari gangguan perubahan alam, maupun kegiatan antropogenik baik berskala global maupun skala lokal (Lasagna et al., 2014). Deposit kerangka

\footnotetext{
${ }^{\circledR}$ Copyright by Management of Aquatic Resources (MAQUARES)
} 
kapur karang dapat menjadi rumah bagi 2 juta spesies biota laut (Wouthuyzen, 2015).

Salah satu pulau penting dan cukup besar di Kepulauan Karimunjawa adalah Pulau Kemujan. Pulau Kemujan merupakan sebuah pulau yang berada di Laut Jawa, bagian dari kepulauan Karimunjawa. Pulau Kemujan terletak di sebelah utara pulau Karimunjawa. Perairan di pulau ini memiliki keanekaragaman jenis terumbu karang yang cukup tinggi dengan berbagai biota lain juga dapat ditemui. Pulau Sintok juga merupakan pulau yang memiliki perairan dengan keanekaragaman karang yang tinggi pula. Kedua perairan ini termasuk ke dalam zona pemanfaatan yang digunakan sebagai wisata bahari. Kondisi lingkungan menentukan sebaran terumbu karang pada suatu ekosistem. Kedalaman suatu perairan juga sebagai penentu sebaran karang khususnya morfologi karang. Menurut English et al., (1994), bentuk pertumbuhan karang dapat dibagi atas acropora dan non- acropora.

Pada saat ini teknik untuk mengevaluasi hasil tutupan karang adalah dengan melihat atau mengukur penutupan karang hidup. Namun demikian, Edinger and Risk (2000), menyatakan bahwa terdapat analisis morfologi yang dapat digunakan sebagai pendukung status penutupan karang. Komposisi morfologi karang di setiap posisi dihitung dari persentase tutupan setiap kategori morfologis, dinormalisasi untuk total tutupan karang hidup di setiap lokasi dan kemudian dianalisis menggunakan diagram r-K-S untuk mengetahui Class conservation morfologi karang.

Penelitian ini bertujuan untuk mengetahui kualitas perairan, struktur terumbu karang, morfologi karang, pengaruh kedalaman terhadap tutupan karang hidup dan pengaruh kedalaman terhadap morfologi karang di Pulau Kemujan dan Pulau Sintok, Karimunjawa.

\section{B. MATERI DAN METODE PENELITIAN}

\section{Materi}

Materi yang digunakan pada penelitian ini adalah kondisi terumbu karang di Pulau Kemujan dan Pulau Sintok. Adapun data primer diperoleh dari lapangan secara langsung yang meliputi data kualitas perairan seperti salinitas, kecepatan arus, $\mathrm{pH}$ dan Photo underwater karang.

\section{Alat dan Bahan}

Alat yang digunakan dalam penelitian ini yaitu seperti GPS, transek garis (roll meter), refraktometer, set scuba diving, camera undrwater, $\mathrm{pH}$ meter, termometer, DO meter, bola arus, botol sampel, alat tulis, underwater paper, laptop, piranti CPCe dan SPSS.

\section{Metode}

Metode penelitian yang digunakan yaitu metode observasi atau survey. Metode ini untuk mendapatkan gambaran yang lebih mendalam dari objek penelitian, yaitu mengetahui struktur terumbu karang berdasarkan Class Conservation dan kedalaman. Adapun metode yang digunakan dalam sampling adalah metode underwater photo transect (UPT).

\section{Penentuan Lokasi Penelitian}

Lokasi penelitian tersebut maka diperoleh titik sampling dua kedalaman mewakili daerah reef flat dan reef slope di Pulau Kemujan dan Pulau Sintok pada kedalaman 5 dan 10 meter, hal tersebut dikarenakan kedalaman 5 meter mewakili daerah reefflat dan 10 meter mewakili daerah reef slope. Adapun garis lintang dan garis bujur pada penentuan lokasi penelitian yaitu stasiun 1 (Pulau Kemujan) Stasiun 1 (Pulau Kemujan) memiliki Garis Lintang (S) :

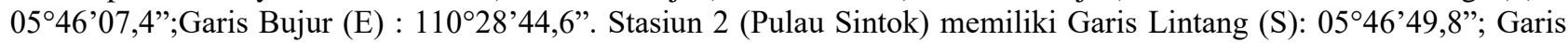
Bujur (E) : $110^{\circ} 30^{\prime} 28,3^{\prime \prime}$.

\section{Pengambilan Data}

Metode pengambilan data untuk penilaian kondisi terumbu karang salah satunya yaitu metode Transek Foto Bawah Air (Underwater Photo Transect = UPT) Giyanto et al., 2010; Giyanto, 2012a; Giyanto, 2012b). Pengambilan data di lapangan dilakukan pada perairan Pulau Kemujan dan Pulau Sintok hanya berupa foto-foto bawah air yang dilakukan dengan menggunakan kamera digital bawah air seperti CANON G15 dengan spesifikasi resolusi kamera minimal $12 \mathrm{MP}$ atau kamera lain yang lebih tinggi minimal pemotretan $2552 \mathrm{~cm}^{2}$ dan telah diberi pelindung tahan air (housing). Hasil pemotretan tersebut kemudian dianalisis menggunakan piranti lunak komputer untuk mendapatkan data-data yang kuantitatif. Proses pengambilan data terumbu karang menggunakan roll meter dan kuadran transek. Terdapat dua kawasan kedalaman dalam penelitian dimana untuk setiap kedalaman terdapat dua kali pengulangan. Pengulangan yang dilakukan yaitu berjarak 3 meter dengan pengulangan lainnya secara pararel. Hal ini dikarenakan kondisi terumbu karang cenderung heterogen. Menurut Supriharyono dan Sigit (2020), bahwa dalam menentukan panjang transek untuk mengetahui kondisi karang, apabila kondisi karang cukup heterogen atau beragam maka panjang transek cukup 10-20 meter saja.Adapun peta lokasi penelitian disajikan pada Gambar 1.

\section{Analisis Data}

Hasil pengambilan data kemudian di analisis menggunakan aplikasi CPCe terdapat beberapa piranti lunak pemrosesan analisis foto salah satunya yaitu CPCe (Coral Point Count with Excel Extensions) dan kemudian dikelompokkan untuk mengetahui morfologi karang berdasarkan Class Conservation sesuai morfologi karang r-K-S. Serta dilakukan analisis untuk mengetahui pengaruh kedalaman terhadap struktur maupun morfologi karang dengan menggunakan piranti lunak SPSS. 


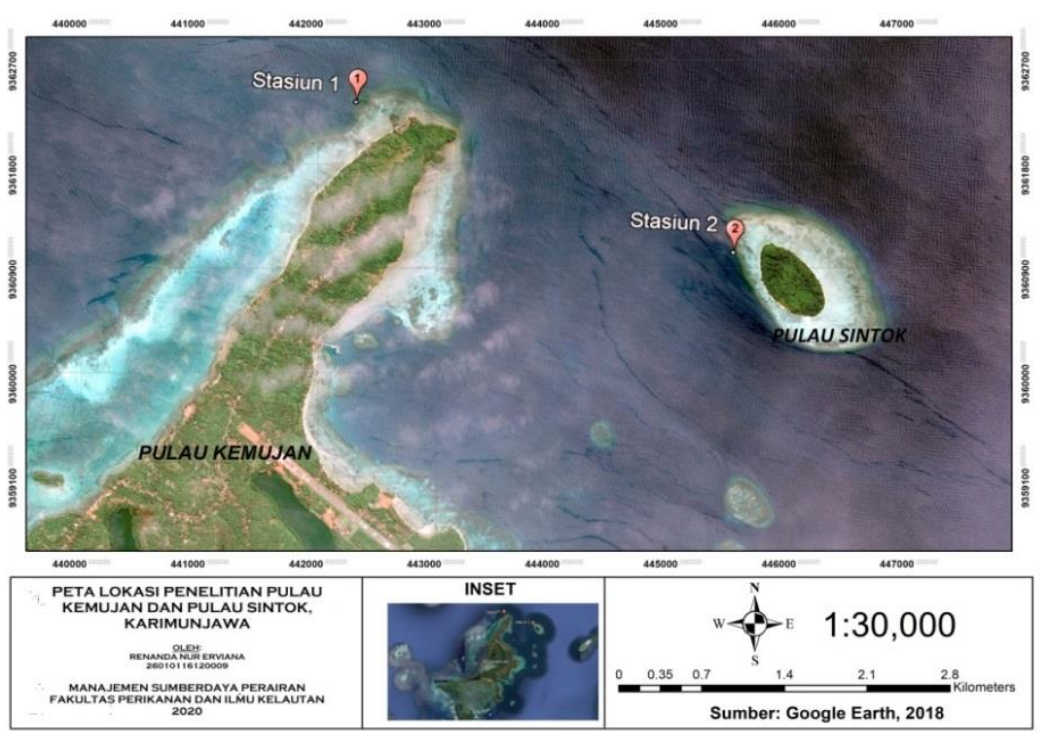

Gambar 1. Peta Lokasi Penelitian

\section{Aplikasi CPCe}

Adapun untuk mendapatkan data kuantitatif, analisis data dilakukan terhadap setiap frame dengan melakukan pemilihan sampel titik acak. Jumlah titik acak (random point) tersebut yaitu sebanyak 30 buah untuk setiap frame yang telah ditentukan secara acak oleh software CPCe dan ini sudah representatif untuk menduga Persentase tutupan kategori maupun substrat (Giyanto et al., 2010). Berdasarkan proses analisis foto yang dilakukan, maka dapat diperoleh nilai Persentase tutupan kategori untuk setiap frame.

Segitiga Morofologi r-K-S

Adapun segitiga morofologi r-K-S dapat dilihat pada tabel 1.

Tabel 1. Segitiga Morfologi r-K-S

\begin{tabular}{|c|c|c|c|}
\hline Grup r-K-S & Conservation & Morfologi & Kelompok r-K-S \\
\hline Ruderal ( $r$ ) & CC 3 & $\begin{array}{l}\text { Seluruh karang Acropora, Tabulate non- } \\
\text { Acropora), Heliopora, Millepora. }\end{array}$ & $\geq 50 \%$ \\
\hline Competitors $(K)$ & $\mathrm{CC} 2$ & $\begin{array}{l}\text { Non- Acropora (Branching, Plate, Foliose, } \\
\text { Encrusting, free-living) }\end{array}$ & $\geq 50 \%$ \\
\hline Stress- tolerator $(S)$ & $\mathrm{CC} 1$ & Massive, Submasive & $\geq 60 \%$ \\
\hline
\end{tabular}

Berdasarkan tabel 1. maka klasifikasi tersebut digunakan dengan menggunakan r-K-S diagram terner (Edinger and Risk 2000), adapun rinciannya yaitu Acropora sebagai ruderal (r) karena pertumbuhan yang cepat namun rapuh (Done, 1982; Karlson and Hurd, 1993; Edinger and Risk, 2000), non-Acropora dengan lifeform bercabang maupun foliose, di kategorikan sebagai competitive-adapted $(\mathrm{K})$ di karenakan pertumbuhannya yang lambat dan dominasi pada terumbu karang Indonesia pada daerah dengan gelombang besar (Edinger dan Risk, 2000; Pardede et al., 2016) Karang Massive dan sub-massive yang lebih toleran terhadap sedimentasi atau eutrofikasi tinggi di klasifikasikan sebagai stress-tolerators (S) (Edinger and Risk, 2000; Kulkarni and Saxena, 2002). Kelas 1 "CC=1" jika persentase terumbu stress-tolerator sama atau melebihi $60 \%$, untuk kelas 2 " $\mathrm{CC}=2$ " bagi terumbu karang competitor $(\mathrm{K})$ dan kelas " $\mathrm{CC}=3$ " bagi terumbu kategori ruderal (r), mempunyai persentase dominasi karang hidup yang sama dengan atau melebihi $50 \%$, jika tidak ada bentuk lifeform pada kelompok r-K-S yang mempunyai persentase seperti yang dijelaskan di atas, maka diklasifikasikan dalam kelas 4 "CC=4", jenis lifeform campuran. (Edinger dan Risk 2000; Kamarumthan et al., 2016).

\section{HASIL DAN PEMBAHASAN}

\section{HASIL}

\section{Parameter Kualitas Perairan}

Berdasarkan penelitan maka kualitas perairan pada Pulau Kemujan dan Pulau Sintok didapatkan hasil variabel kecerahan 4 - 4,42 m, pH 7,33 - 7,44, salinitas $34 \%$, temperatur $29-30{ }^{\circ} \mathrm{C}$, kecepatan arus $0,120-0,08 \mathrm{~m} / \mathrm{s}$ dan TSS $0,0002-0,0004 \mathrm{mg} / \mathrm{L}$ hal ini menunjukkan kondisi perairan tergolong normal dan hasil tidak melebihi nilai optimum kecuali kandungan DO sebesar 9,61- 10,48 mg/L.

\section{Struktur Terumbu Karang}

Struktur terumbu karang pada Pulau Kemujan memiliki tutupan karang dan kategorinya yaitu karang hidup 44,11$53,67 \%$, karang mati 20,11 - 23,22\%, abiotik (pecahan karang, pasir) 17,11 - 21,44\%, sedangkan pada Pulau Sintok memiliki persentase karang hidup 46,78-76,22\%, karang mati 9,33 - 12,56\%, abiotik (pecahan karang, pasir) $14-$ $38,89 \%$. Secara keseluruhan struktur terumbu karang di kedua stasiun tergolong masuk kategori sedang hingga sangat 
baik sesuai Kepmen LH tahun 2001. Adapun persentase karang hidup berkisar 25,56 -76,22\%.

\section{Persentase Bentuk Pertumbuhan karang}

Berdasarkan hasil penelitian maka diperoleh persentase bentuk pertumbuhan karang pada kedua stasiun yang disajikan pada gambar 2. (Stasiun 1 Reef Flat ), gambar 3. (Stasiun 1 Reef Slope), gambar 4. (Stasiun 2 Reef Flat ), dan gambar 5. (Stasiun 2 Reef Slope).

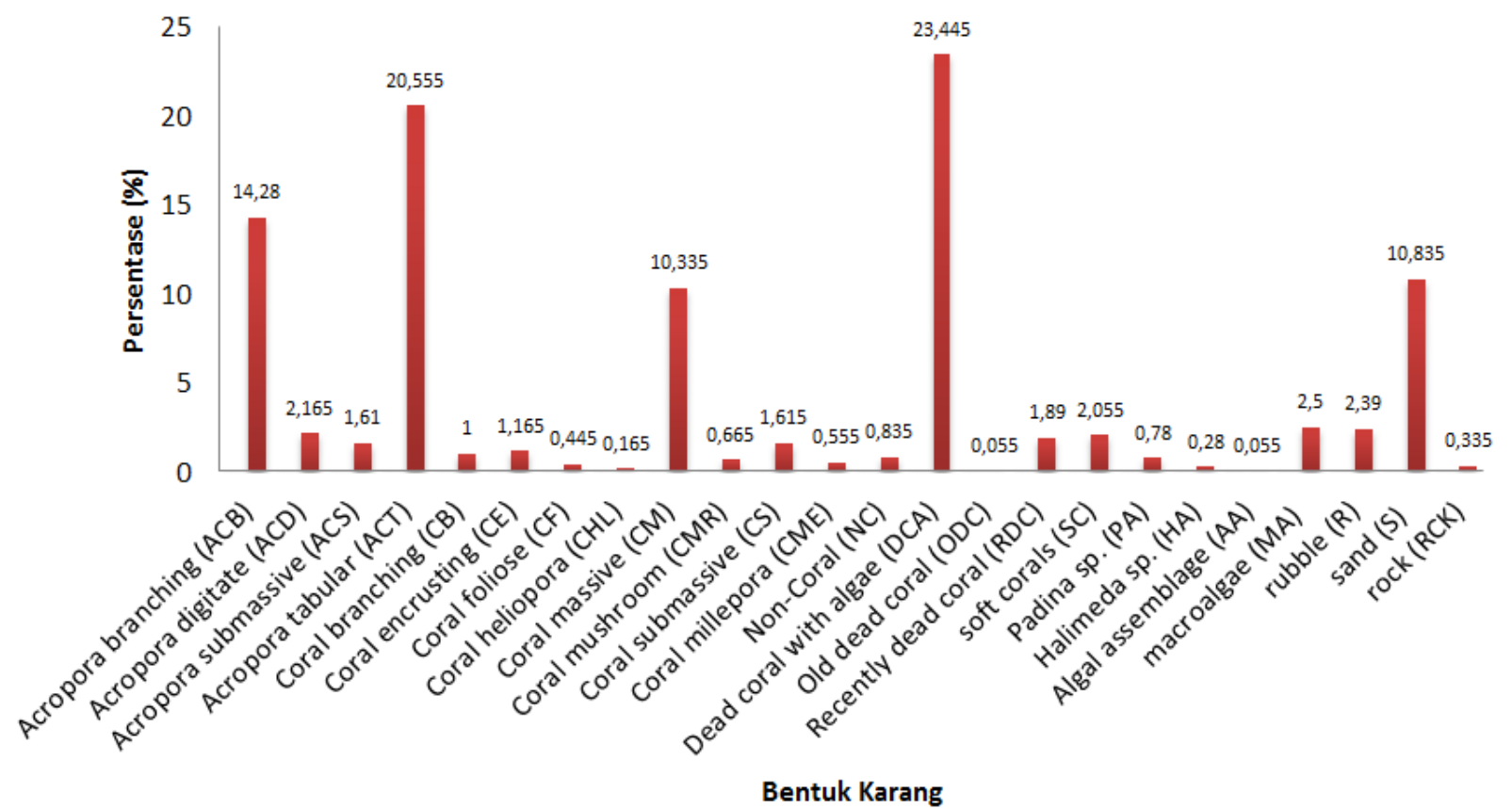

Gambar 2. Grafik Persentase Bentuk Pertumbuhan Karang Stasiun 1 Reef Flat

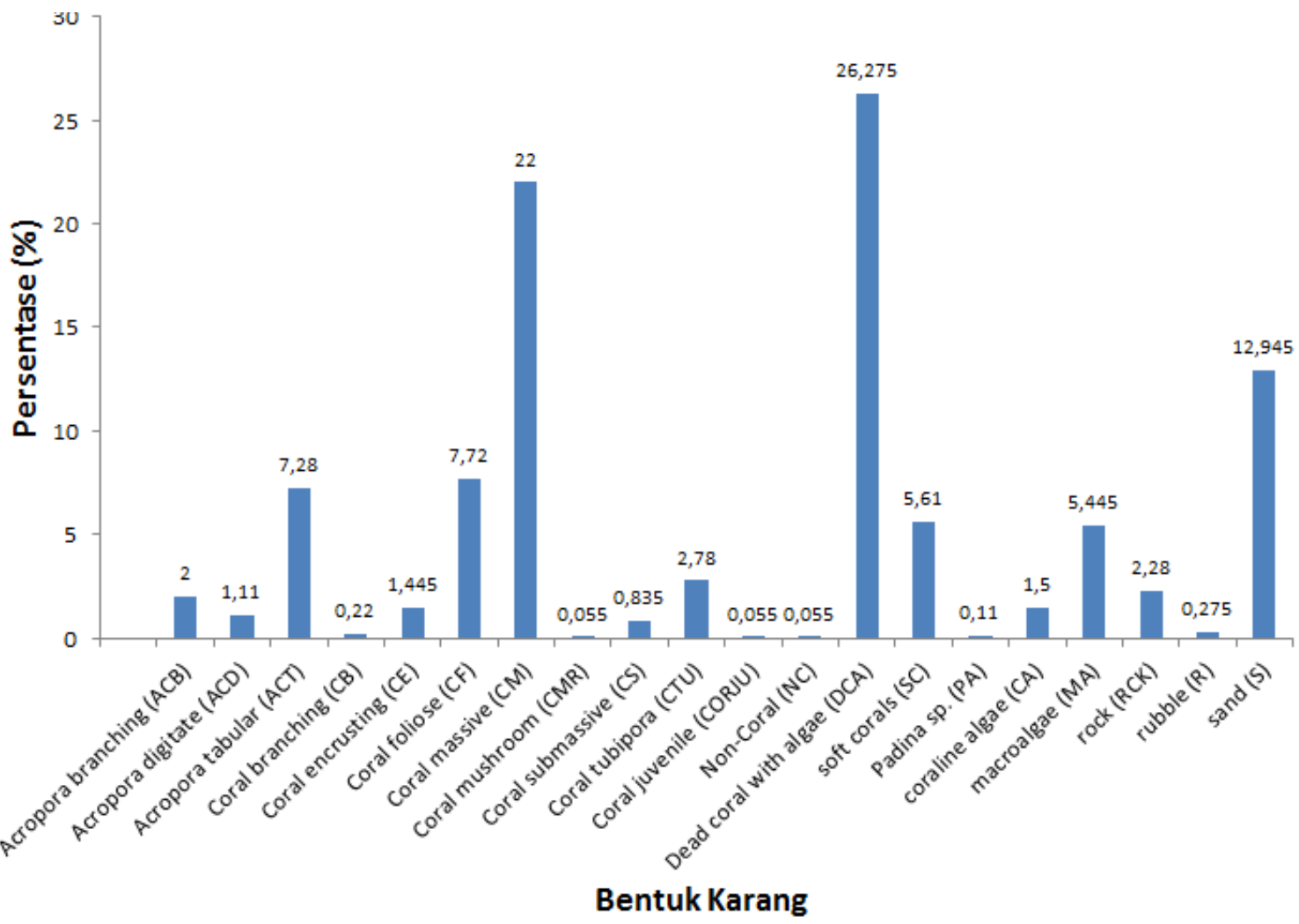

Gambar 3. Grafik Persentase Bentuk Pertumbuhan Karang Stasiun 1 Reef Slope 


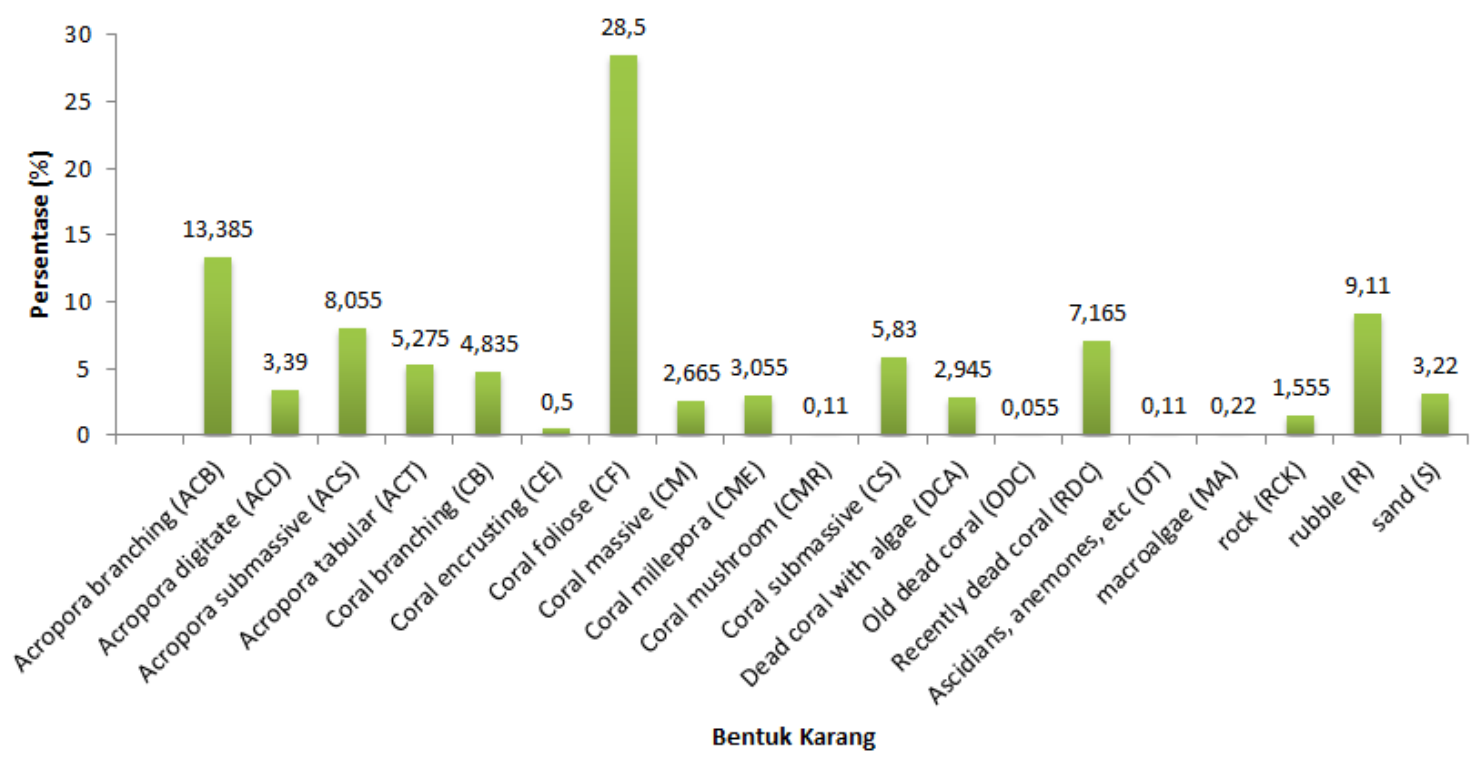

Gambar 4. Grafik Persentase Bentuk Pertumbuhan Karang Stasiun 2 Reef Flat

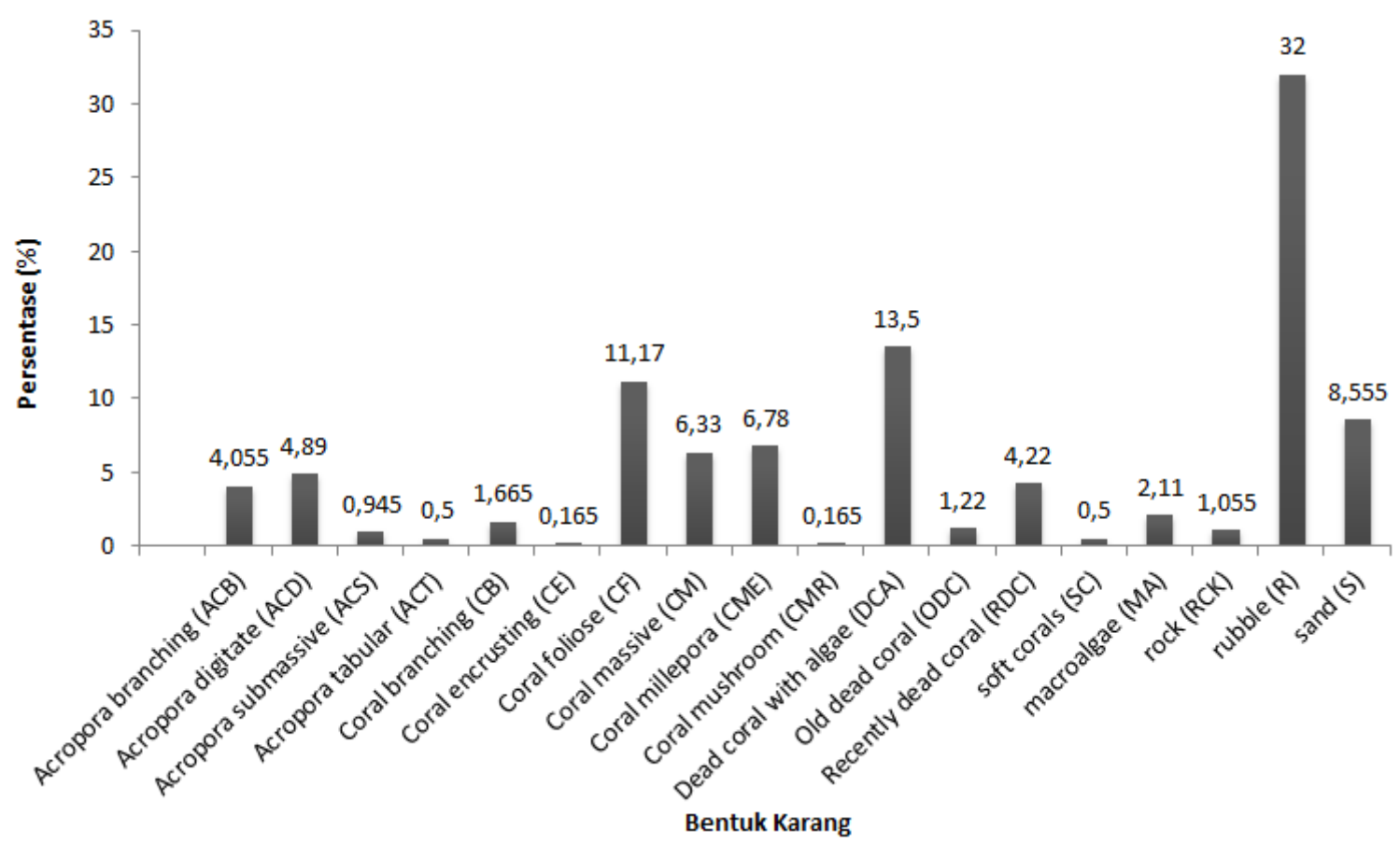

Gambar 5. Grafik Persentase Bentuk Pertumbuhan Karang Stasiun 2 Reef Slope

\section{Morfologi Karang Stasiun 1}

Morfologi karang pada stasiun 1 dapat diketahui hasilnya seperti pada Tabel 2.

Tabel 2. Coral Morphology Stasiun 1

\begin{tabular}{lccc}
\hline \multirow{2}{*}{ Lokasi } & \multicolumn{3}{c}{ Coral Morphology } \\
\cline { 2 - 4 } & $\mathbf{\%}$ & $\mathbf{\%}$ & $\mathbf{K} \mathbf{S}$ \\
\hline Reef Flat I & 44,66 & 49,78 & 5,56 \\
Reef Flat II & 34 & 47,66 & 18,34 \\
\hline Rata- rata & $\mathbf{3 9 , 3 3}$ & $\mathbf{4 8 , 7 2}$ & $\mathbf{1 1 , 9 2}$ \\
\hline Reef Slope I & 10,11 & 66,33 & 23,56 \\
Reef Slope II & 10,67 & 67,22 & 22,11 \\
\hline Rata-rata & $\mathbf{1 0 , 3 9}$ & $\mathbf{6 6 , 7 8}$ & $\mathbf{2 2 , 8 3}$ \\
\hline
\end{tabular}

Berdasarkan tabel 2. area reef flat memiliki rata-rata persentase terendah pada kelompok (S) yaitu 11, $92 \%$ dan memiliki persentase tertinggi kelompok (K) yaitu $48,72 \%$. Maka dapat diketahui bahwa untuk stasiun 1 pada area 
reef flat tidak memiliki dominasi morfologi karang. Hal ini dikarenakan persentase karang tidak ada yang memiliki nilai $\geq 50 \%$. Sedangkan untuk area reef slope terdapat persentase berbanding terbalik dengan area reef flat. Persentase terendah justru terdapat pada kelompok (r) sebesar 10,39\%, dan persentase kelompok (S) yaitu 22,83\%. Namun demikian, pada area reef slope memiliki dominasi kelompok kompetitor $(\mathrm{K})$ dimana banyak ditemukan karang jenis branching dan foliose yang memiliki persentase $\geq 50 \%$ yaitu (66,33-67,22\%). Adapun morfologi karang pada stasiun 2 dapat dilihat pada Tabel 3.

Tabel 3. Coral Morphology Stasiun 2

\begin{tabular}{lccc} 
& \multirow{2}{*}{ Lokasi } & \multicolumn{3}{c}{ Coral Morphology } & & \%S \\
\cline { 2 - 4 } & \%r & $\mathbf{\%}$ & 6,66 \\
\hline Reef Flat I & 27,21 & 66,13 & 10,33 \\
Reef Flat II & 37,33 & 52,34 & $\mathbf{8 , 4 9}$ \\
\hline Rata- rata & $\mathbf{3 2 , 2 7}$ & $\mathbf{5 9 , 2 3}$ & 0,44 \\
\hline Reef Slope I & 14,78 & 84,78 & 12,22 \\
Reef Slope II & 19,56 & 68,22 & $\mathbf{6 , 3 3}$ \\
\hline Rata-rata & $\mathbf{1 7 , 1 7}$ & $\mathbf{7 6 , 5}$ & \\
\hline
\end{tabular}

Berdasarkan tabel 3. maka dapat diketahui bahwa untuk stasiun 2 pada area reef flat pengulangan I maupun II memiliki rata-rata persentase terendah pada kelompok (r) yaitu 8,49\% dan persentase tertinggi pada kelompok (K) dimana terdapat karang dengan bentuk branching, foliose dan encrusting sebesar 52,34 - 66,13\%. Area reef slope memiliki rata-tara persentase terendah pada kelompok (r) yaitu 6,33\% dan persentase tertinggi pada kelompok (K) hingga 76,5\%. Hal ini menunjukkan adanya dominasi karang dengan morfologi branching dan foliose. Secara keseluruhan, pada stasiun 2 area reef flat maupun area reef slope terdapat dominasi morfologi karang kelompok kompetitor (K) dimana dominasi karang jenis branching dan foliose yang memiliki persentase $\geq 50 \%$ yaitu (68,22$84,78 \%)$.

\section{PEMBAHASAN \\ Parameter Kualitas Perairan}

Berdasarkan data yang telah diperoleh maka hasil pengukuran temperatur pada kedua stasiun di Pulau Kemujan dan Pulau Sintok berkisar $29-30^{\circ} \mathrm{C}$, suhu tersebut tergolong tinggi dikarenakan saat pengambilan data kondisi cuaca sangat cerah dan cenderung panas. Menurut Nybakken (1992), menyatakan bahwa suhu optimal karang mencapai 23$25^{\circ} \mathrm{C}$. Hasil pengukuran salinitas menunjukkan nilai yang normal yaitu 34\%. Hal ini sesuai dengan KEPMEN LH No 51 Tahun 2004 bahwa salinitas yang baik untuk terumbu karang berkisar 33-34\%o. Nilai pH pada kedua lokasi penelitian bernilai 7,33- 7,44, nilai tersebut masih tergolong normal. Menurut KEPMEN LH No 51 Tahun 2014 bahwa nilai $\mathrm{pH}$ di laut berkisar 6,5 - 8,5. Berdasarkan pengukuran DO didapatkan hasil berkisar 9,61-10,48 mg/L. Kadar tersebut sesuai dengan KEPMEN LH No.51 tahun 2004 yang menyatakan bahwa oksigen terlarut di laut yang baik yaitu lebih dari $5 \mathrm{mg} / \mathrm{L}$, namun tingginya kandungan DO hal ini disebabkan adanya arus dalam pada perairan sehingga terjadi turbulensi yang mengakibatkan kenaikan DO. Adapun hasil uji TSS yang dilakukan, maka perairan Pulau Kemujan dan Pulau Sintok memiliki nilai berkisar 0,0002- 0,0004 mg/L. Hal ini menunjukkan perairan tersebut masih tergolong normal ditandai dengan kualitas air yang jernih.

\section{Struktur Terumbu Karang}

Berdasarkan analisis menggunakan software CPCe maka dapat diperoleh hasil tutupan karang hidup pada stasiun 1 area reefflat sebesar 53,67-55,44\% dimana juga terdapat kategori dead coral sebesar 20,11-20,67\%, pecahan karang 5,67- 21,44\% dan sisanya adalah algae. Hal ini menunjukkan kondisi terumbu karang pada kedalaman 5 meter masih tergolong baik. Hal ini diperkuat oleh Supriharyono (2007), bahwa rata-rata tutupan karang di Kepulauan Karimunjawa yang berada pada zona pemanfaatan dan pariwisata berkisar $40-60 \%$. Sedangkan pada area reef slope diperoleh hasil persentase tutupan terumbu karang berkisar 44,11- 46,89\% dan terdapat dead coral 23,22 - 29,33\%. Hal ini menunjukkan bahwa kondisi terumbu karang pada kedalaman 10 meter dalam keadaan sedang.

Kondisi terumbu karang pada stasiun 2 di area reef flat memiliki hasil persentase tutupan karang hidup yang lebih tinggi dibandingkan stasiun 1. Persentase yang dihasilkan berkisar $75-76,22 \%$ dan memiliki persen dead coral 9,33-11\%. Hal ini menunjukkan kondisi terumbu karang memiliki kriteria sangat baik. Hal ini menunjukkan kondisi terumbu karang memiliki kriteria sangat baik. Menurut KEPMEN LH (2001), bahwa kategori terumbu karang sangat baik memiliki persentase tutupan 75-100\%. Sedangkan untuk area reef slope yang memiliki kedalaman 10 meter diperoleh hasil tutupan karang yang lebih rendah yaitu 25,56-46,78\%. Selain itu juga terdapat dead coral berkisar 12,56-25,67\% dan abiotik (pecahan karang, pasir) sebesar 38,89-44,33\%. Hal ini menunjukkan bahwa tutupan karang memiliki kategori sedang. Berdasarkan data yang diperoleh maka, terdapat perbedaan yang signifikan antara kawasan reef flat dengan reef slope dimana penurunan persentase tutupan karang semakin dalam perairan semakin rendah. Hal ini juga dipengaruhi adanya kerusakan karang akibat bleaching yang terbawa melalui arus bawah sehingga dapat membawa pecahan karang ke kawasan reef slope. Menurut Ias et al., (2014), bahwa Pulau Sintok menjadi tujuan wisata

\footnotetext{
${ }^{\odot}$ Copyright by Management of Aquatic Resources (MAQUARES)
} 
snorkeling sehingga pecahan karang rata-rata mencapai $20 \%$.

\section{Persentase Terumbu Karang Berdasarkan Class Conservation}

Persentase terumbu karang berdasarkan class conservation stasiun 1 pada tiap kedalaman memiliki kecenderungan yang berbeda. Hal ini juga dibuktikan adanya karang dengan jenis morfologi seperti karang branching dan foliose, dimana karang tersebut memiliki pertumbuhan yang lambat serta berada pada daerah dengan gelombang besar. Menurut Edinger and Risk (2000) ; Pardede et.al., (2016), menyatakan bahwa karang yang memiliki pertumbuhan yang lambat dan berada pada daerah yeng memiliki gelombang yang besar termasuk dalam kelompok moroflogi kompetitor. Berdasarkan data yang telah diperoleh maka, Pulau Kemujan memiliki kecenderungan termasuk kedalam Class Conservation ("CC" $=2$ ) atau kelompok Kompetitor, walaupun demikian terdapat persentase pada area reefflat berkisar 48,72 \%. Hal ini berarti pada kedalaman 5 meter Pulau Kemujan tidak memiliki dominasi morfologi karang ("CC”=4) atau mix coral morphology dimana terdapat kelompok ruderal (r) 39,33\% karang jenis ini memiliki pertumbuhan yang cepat namun mudah rapuh.

Persentase terumbu karang pada stasiun 2 dapat diketahui bahwa terdapat banyak morfologi karang seperti branching, foliose dan encrusting. Maka, secara keseluruhan pada stasiun 2 memiliki morfologi karang dengan dominasi kelompok (" $\mathrm{CC}=2$ ) yaitu Competitors. Menurut Edinger and Risk (2000), kelompok karang kompetitors merupakan kelompok yang memiliki pertumbuhan yang lambat namun tersebar didaerah yang memiliki gelombang yang besar. Menurut Erdmann et al.,(1997), metode taksonomi-independen ini dapat membantu pengelola terumbu membuat keputusan yang lebih terinformasi tentang terumbu mana yang harus diberi tingkat perlindungan terbesar dalam zonasi kawasan lindung laut.

Dominasi morfologi karang pada kedua stasiun yaitu Pulau Kemujan dan Pulau Sintok merupakan ciri dari daerah terumbu karang yang berada dengan gelombang yang besar (Bak and Povel, 1989; Edinger and Risk, 2000; Pardede dkk, 2016). Daerah dengan gelombang yang besar merupakan faktor mekanik yang dapat membatasi ukuran dari koloni, apabila karang yang tumbuh merupakan karang bercabang maka dengan bertambah besarnya karang, semakin mudah karang tersebut rusak akibat adanya gelombang. Akibat struktur karang yang tidak kuat menahan beban cabang dibanding dengan area yang melekat pada substrat, sehingga koloni semakin tidak stabil. Namun demikian, karang bercabang tidak menutup kemungkinan fragmen yang patah dapat bertahan dan tumbuh menjadi koloni yang besar, sedangkan koloni karang massive, semakin besar koloni maka semakin kuat menahan gelombang, bahkan terumbu karang pada daerah gelombang hanya didominasi oleh beberapa jenis karang saja yang dapat bertahan (Barnes and Hughes, 1999).

Menurut Akhmad et al., (2018), bahwa dalam penelitiannya di Pulau Karimunjawa destinasi wisata spot Ujung Bintang dan spot Maer terdapat koloni karang kategori K dengan kisaran 86,44 - 92, 96\%. Hal ini menunjukkan banyaknya karang yang mempunyai ciri pertumbuhan yang cepat dan merupakan ciri karang yang hidup di gelombang yang besar.

Kelas konservasi seperti yang ditunjukkan oleh diagram terner adalah prediktor kekayaan spesies karang yang lebih dapat diandalkan daripada tutupan karang hidup, kondisi terumbu atau indeks kematian (Gomez dan Yap, 1988; Gomez, 1994). Berdasarkan hasil uji statistik menggunakan uji-t maka dapat ditarik kesimpulan bahwa untuk setiap stasiun tidak memiliki perbedaan yang nyata dan tidak terjadi signifikansi terhadap morfologi karang dengan kedalaman. Hal ini berarti pada setiap data diasumsikan sama atau $\mathrm{H}_{0}=$ diterima.

\section{KESIMPULAN}

Berdasarkan penelitian maka diperoleh kesimpulan yaitu secara keseluruhan struktur terumbu karang di kedua stasiun tergolong masuk kategori sedang hingga sangat baik (25,56-76,22\%). Dominasi karang pada kedua stasiun terdapat kelompok kompetitors (K), dimana memiliki dominasi morfologi seperti branching maupun foliose. Adapun kisaran persentasenya 59,23 - 66,77\% ("CC"=2). Tidak ada pengaruh antara kedalaman terhadap living coral cover di Pulau Kemujan dan Pulau Sintok, serta tidak ada pengaruh antara kedalaman terhadap morfologi karang secara nyata (sig F > $0,05)$.

\section{UCAPAN TERIMAKASIH}

Penulis mengucapkan terimakasih kepada Dr. Ir. Suryanti, M.Pi dan Dr. Aninditia Sabdaningsih, S.Si, M.Si yang telah memberikan saran dalam penulisan hasil penelitian ini, serta kepada seluruh pihak yang telah membantu dan memberikan dukungan untuk menyelesaikan penelitian ini.

\section{DAFTAR PUSTAKA}

Akhmad, D.S., Supriharyono dan Purnomo, P.W. 2018. Potensi Kerusakan Terumbu Karang pada Kegiatan Wisata Snorkeling di Destinasi Wisata Taman Nasional Karimunajwa. Jurnal Ilmu dan Teknologi Kelautan Tropis, 10 (2): 419-429.

Bak, R.P.M., and G.D.E. Povel. 1989. Ecological Variabels, Including Physiognomic Structural Attributes, and Classification of Indonesia Coral Reefs. Neth. Sea Research, 23 92) : 95 - 106.

Barnes, R. S. K., and R.N. Haughes. 1999. An Introduction to Marine Ecology. 3th ed., B;acwell Science Ltd, Oxford, 
$286 \mathrm{p}$.

Edinger, E.N., and Risk, M.J,.2000. Reef Classification by coral Morphology Predicts coral reef conservation value. Biological Conservation, 92 (1) :1-13.

English, S., Wilkinson, C., Baker,V,. 1994. Survey Manual For Tropical Marine Resources. ASEAN - Australia Marine Science Project Living Coastal Resources. Australiaan institute of Marine Science. Townsville. 390p.

Erdmann, M.V., Caldwell, R.L., 1997. Stomatopod crustaceans as indicators of marine pollution stress on coral reefs. Proc. 8th Intl Coral Reef Sym. 2, 1521 \pm 1526.

Done, T.K., 1982. Patterns in the distribution of coral communities across the central Great Barrier Reef. Coral Reefs, 1 : $95-107$.

Giyanto, A.E.Manuputty, M. Abrar dan E.M. Siringoringo. 2014. Panduan Monitoring Kesehatan terumbu Karang. Jakarta: $91 \mathrm{hlm}$

Giyanto; B.H. Iskandar; D. Soedharma \& Suharsono. 2010. Effi siensi dan akurasi pada proses analisis foto bawah air untuk menilai kondisi terumbu karang. Oseanologi dan Limnologi di Indonesia 36 (1): 111-130.

Giyanto. 2012a. Kajian tentang panjang transek dan jarak antar pemotretan pada penggunaan metode transek foto bawah air. Oseanologi dan Limnologi di Indonesia 38 (1): 1-18.

Giyanto. 2012b. Penilaian Kondisi Terumbu Karang Dengan Metode Transek Foto Bawah Air.Oseanologi dan Limnologi di Indonesia 38 (3): 377-390.

Gomez, E.D., AlinÄo, P.M., Yap, H.T., Licuanan, W.Y., 1994. A review of the status of Philippine reefs. Marine Pollution Bulletin 29, 62 \pm 678 .

Gomez, E.D., Yap, H.T., 1988. Monitiring reef condition. In: Kench-ington, R.A., Hudson, B.E.T. (Eds.), Coral reef management hand-book. UNESCO regional $0^{\bullet}$ ce for science and technology for southeast Asia (ROSTSEA), Jakarta, pp. $171 \pm 178$.

Ias, B., Munasik dan Koesoemadji. 2014. Kondisi Terumbu Karang pada Lokasi Wisata Snorkeling di Kepulauan Karimunjawa, Jawa Tengah. Journal of Marine Research, 182-201.

Kamarumtham, K., Z. Ahmad, N.H. Halid, S. Saad, M. Fikri, A. Khodzori, M.H. Yusof, and M.F.M. Hanafiah. 2016. Diversity and Distribution of Coral Lifeforms in Tioman Island. Transactions on Science and Technology, 3 (22):367-373.

Karlson, R.H., and L.E. Hurd. 1993. Disturbance, Coral Reef Communities, and Changing Ecological Paradigms. Coral Reefs, $12: 117-125$.

KEPMEN LH No 51 Tahun 2004. Baku Mutu Air Laut untuk Biota Laut. Kementerian Negara Bidang Lingkungan Hidup Republik Indonesia.

Kepmen LH No 51 2001. Baku Mutu Air Laut untuk Biota Laut. Kementerian Negara Bidang Lingkungan Hidup Republik Indonesia.

Kulkarni, S., and A. Saxena. 2002. The Conservation Status of Coral Reefs of Andaman and Nicobar Islands. Coral Reef Degradation in the Indian Ocean, 103p.

Lasagna, R., G. Gnone, M. Taruffi, C. Morri, C.N. Bianchi, V. Parravicini, and S. Lavorano. 2014. A New Synthetic Index to Evaluate Reef Coral Condition. Ecological Indicators, 40:1-9.

Nybakken, J.W. 1992. Biologi Laut Suatu Pendekatan Ekologis. Jakarta: Penerbit Djambatan.

Pardede, S., A.S.R. Tarigan, F, Setawan, E. Muttaqin, dan Muhidin. 2016. Laporan Teknis: Monitoring Ekosistem Terumbu Karang Taman Nasional Karimunjawa 2016. Wildlife Conservatiob Society, Bogor, Indonesia, 55 hlm.

Surat Keputusan Direktur Jenderal PHKA No. SK 28/IV-SET/2012 tentang Zonasi Taman Nasional Karimunjawa.

Supriharyono dan Sigit Febrianto. 2020. Buku Ajar Koralogi Potensi dan Permasalahan. Semarang.

Supriharyono. 2007. Konservasi Ekosistem Sumberdaya Hayati di Wilayah Pesisir dan Laut Tropis. Yogyakarta: Pustaka Pelajar.

Westmacott, S., K. Teleki., S. Wells dan J. West. 2000. Pengelolaan Terumbu Karang yang Telah Memutih dan Rusak Kritis. Inggris : IUCN (The World Conservation Union).

Wouthuyzen, S., M. Abrar, dan J. Lorwens. 2015. Pengungkapan Kejadian Pemutihan Karang Tahun 2010 di Perairan Indonesia Melalui Analisis Suhu Permukaan Laut. Oseanologi dna Limnologi di Indonesia. 1 (3) : 305 - 327. 